\title{
Effect of Trap Orientation and Interval Distance on Captures of Isoceras sibirica Alpheraky (Lepidoptera: Cossidae)
}

\author{
Hongxia Liu ${ }^{1}$, Zhixiong Liu ${ }^{1}$, Haixia Zheng ${ }^{1}$, Meihong Yang ${ }^{1}$, Jinlong Liu ${ }^{1} \&$ Jintong Zhang ${ }^{1}$ \\ ${ }^{1}$ Institute of Chemical Ecology, Shanxi Agricultural University, Shanxi, China \\ Correspondence: Jintong Zhang, Institute of Chemical Ecology, Shanxi Agricultural University, Shanxi, 030801, \\ China. Fax: 86-0354-6286990. E-mail: sxaulhx@163.com
}

Received: December 9, 2014

Accepted: January 27, 2015 Online Published: March 15, 2015

doi:10.5539/jas.v7n4p161

URL: http://dx.doi.org/10.5539/jas.v7n4p161

\begin{abstract}
Studies were conducted in an asparagus field in taigu $\left(37^{\circ} 18^{\prime} \mathrm{N}, 112^{\circ} 29^{\prime} \mathrm{E}, 824 \mathrm{~m}\right.$ above sea level), Shanxi province, China, May to June, 2009 to 2011, to evaluate the influence of interval distance and orientation on catches of the carpenterworm, Isoceras sibirica Alpheraky (Lepidoptera: Cossidae) in pheromone-baited traps. The results showed that catches of male I. sibirica moths in upwind were higher than in other traps for any intertrap distances. When intertrap distances were shorter than $30 \mathrm{~m}$, interference between traps occurred. These results reveal the effective trap orientation and interval distance for I. sibirica and thus provide guidelines for improving the effectiveness of traps in monitoring and controlling I. sibirica in fields.
\end{abstract}

Keywords: carpenterworm, monitoring and controlling, sex pheromone, trap orientations, trap interval distances

\section{Introduction}

The carpenterworm, Isoceras sibirica Alpheraky (Lepidoptera: Cossidae), is one of the major pest of Asparagus officinalis Linn. in China, causing significant yield losses (Duan et al., 2008). To date, no effective measures for controlling I. sibirica are available; this is due to the root-boring habit of the larvae. The use of synthetic sex pheromones to interfere with reproduction offers an environmental friendly measure to control the pest. Sex pheromones are species-specific and highly selective. They are valuable tools for use in integrated pest management as they are non-toxic and do not represent a health risk to humans and animals. Indeed, the use of pheromones has been reported for a number of insect species, for such purposes as monitoring emergence patterns (Patricia et al., 2008), monitoring pest populations for management decisions (Kehat et al., 1992), assessing the levels of insecticide resistance in pest populations (Haynes et al., 1986, 1987), luring and trapping adult males to suppress pest populations (Zhang et al., 2002), and for mating disruption (Higbee et al., 2008; Il'Ichev et al., 2006; Stelinski et al., 2007).

The effectiveness of pheromone-baited traps in capturing insects may be influenced by many factors, including distance of traps (Schlyter, 1992; Byers, 1999; Laboke et al., 2000), environment (Jansson et al., 1989; Laboke et al., 2000; Sappington \& Spurgeon, 2000), trap type and trap height (Murad, 2001; Sarzynski, 2004). One of these factors is the density of traps, intertrap distances may affect the number of males captured because of interference between traps. When traps are placed close to each other, their radius of attraction may overlap. Furthermore, the interaction of traps is not constant with distance, but varies with lure concentration and wind conditions. By reducing the pheromone release, the active space of a trap decreases because the average concentration of pheromone downwind from the traps decreases (Bradshaw et al., 1989; Judd \& Borden, 1989). In I. sibirica, active components present within the extract from the female sex pheromone gland are (Z)-9-tetradecenyl acetate (Z9-14:Ac), (Z)-7-tetradecenyl acetate (Z7-14:Ac), and (Z)-9-hexadecadecenyl acetate (Z9-16:Ac) (Zhang et al., 2011). However, factors relative with traps of I. sibirica in field remains unknown, so examination of trap orientation and interval distance will be required for successful implementation of pheromone-based trapping for this insect. Our goals were to determine the effects of trap location and interval distance on efficiency of capture of I. sibirica in pheromone-baited traps in Asparagus growing areas. Based on our results, we recommend steps for implementing an effective pheromone-baited trapping program against $I$. sibirica in field. 


\section{Materials and Methods}

\subsection{Experimental Setup}

The study was conducted in an asparagus field in taigu $\left(37^{\circ} 18^{\prime} \mathrm{N}, 112^{\circ} 29^{\prime} \mathrm{E}, 824 \mathrm{~m}\right.$ above sea level), Shanxi province, China, May to June, 2009 to 2011, during the main peak periods of I. sibirica adult moth emergence and flight in this region. Traps were hung on wooden supports, 0.5 to $1 \mathrm{~m}$ in height, and set at $30 \mathrm{~m}$ intervals for the trap orientation and intertrap distance tests. Traps were deployed in arrays of nine traps in a $3 \times 3$ grid pattern with 10, 20, 30, 40, or $50 \mathrm{~m}$ between traps (Figure 1). Each treatment was replicated four times. The minimum distance between neighboring plots was $50 \mathrm{~m}$. This experiment used 180 traps. The prevailing winds were from the south-east (local meteorological data for the past ten years). Trap catches were checked every morning and captured moths were recorded and removed daily.

\subsection{Statistical Analysis}

An assumption of normality was tested for all data sets with the Shapiro-Wilk test. If the null hypothesis that data were normally distributed was rejected, count data were transformed with a square-root transformation to stabilize variances (Snedecor \& Cochran, 1967). If the transformed data were normally distributed (Shapiro-Wilk test), analysis of variance (ANOVA) was used and means with significant differences were separated using Tukey's studentized range test. Otherwise, the data were analyzed with a Kruskal-Wallis parametric ANOVA of mean ranks.

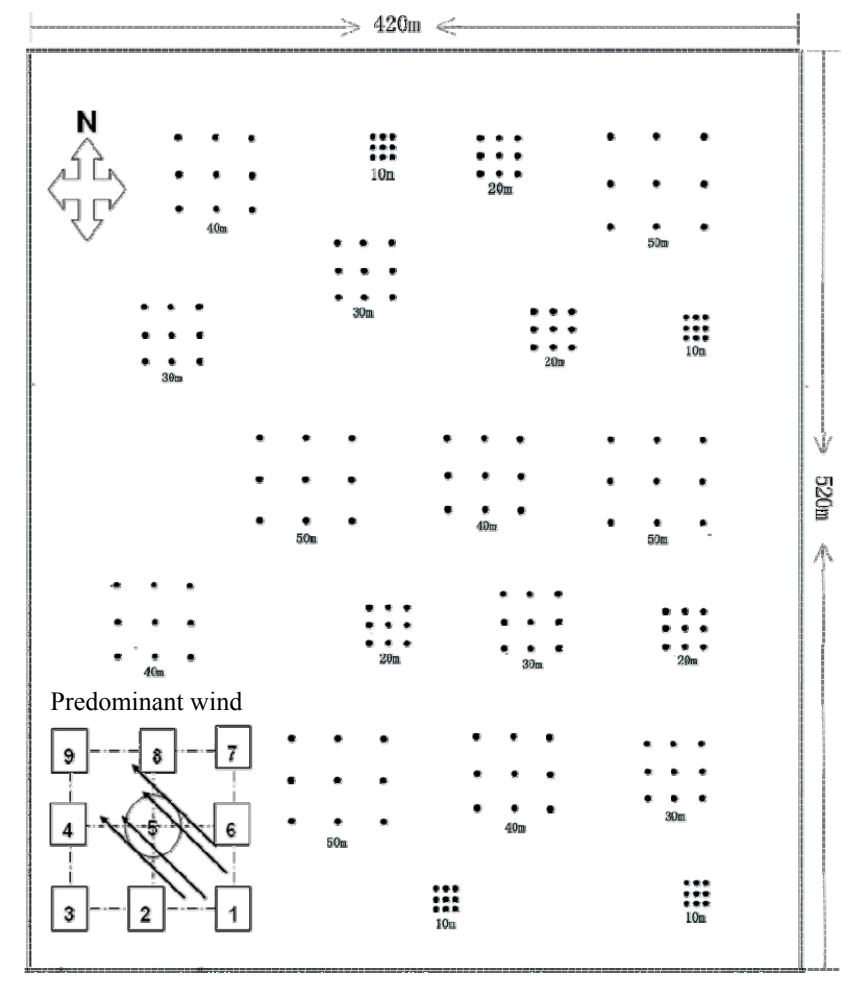

Figure 1. Schematic representation of locations of the I. sibirica pheromone-baited traps, showing arrays of 10, 20, 30, 40 and $50 \mathrm{~m}$ distance between traps, and the position relative to the cardinal directions and prevailing wind. Arabic numerals in panels expressed the serial numbers of trap position. $\bullet$ : I. sibirica Sex Pheromone-Baited Trap

The male capture per square metre as a function of grid distances was estimated using the non-linear regression function $\mathrm{y}=\mathrm{axb}$, where $\mathrm{y}$ is the density of male I. sibirica captured per square metre, $\mathrm{x}$ is the grid distance, and a and $b$ are constants obtained as fitted parameters. The number of males captured per square meter for each inter-trap distance was estimated by the ratio of the total number of males captured in nine traps to the total area within the trap array for each inter-trap distance (Bacca et al., 2006). All analyses were done with SPSS for Windows Version 16.0 software. 


\section{Results}

\subsection{Effect of Trap Orientation}

We recorded significantly higher male moth captures on pheromone-baited traps located the upwind edge of grids than the downwind edge, but differences were not significant for any intertrap distance $(10 \mathrm{~m}: \mathrm{H}=1.5, \mathrm{df}=$ $8, \mathrm{P}=0.9>0.05 ; 20 \mathrm{~m}: \mathrm{H}=5.4, \mathrm{df}=8, \mathrm{P}=0.7>0.05 ; 30 \mathrm{~m}: \mathrm{H}=5.8, \mathrm{df}=8, \mathrm{P}=0.7>0.05 ; 40 \mathrm{~m}: \mathrm{H}=4.3, \mathrm{df}=$ $8, \mathrm{P}=0.8>0.05 ; 50 \mathrm{~m}: \mathrm{H}=2.4, \mathrm{df}=8, \mathrm{P}=0.9>0.05$ ) (Figure 2).
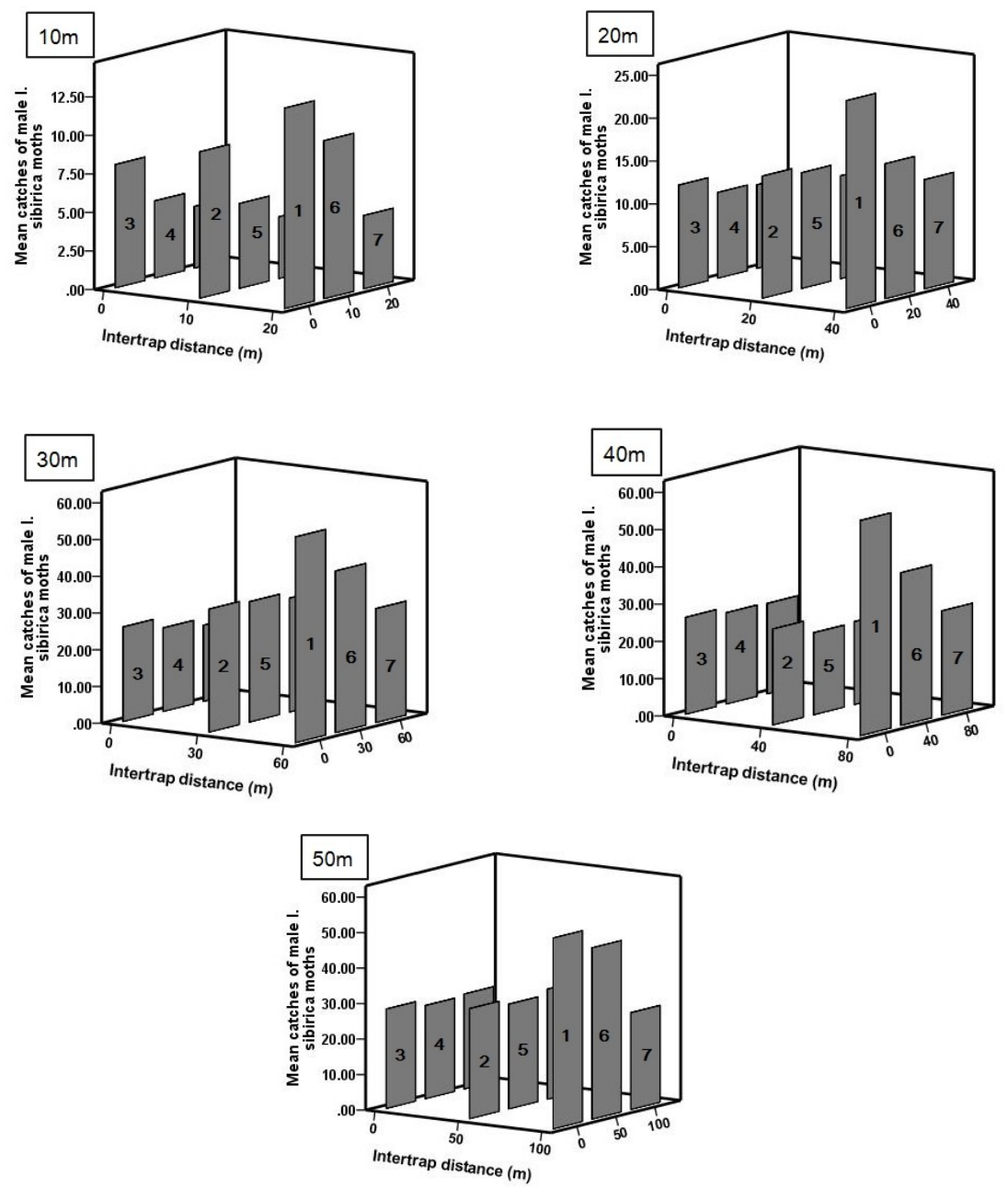

Figure 2. Effect of trap position within grids with different intertrap distances (shown in the upper left of each graph) on mean number of male $I$. sibirica moths captured per trap during the entire flight season. Trap position had no significant effect on mean catch $(10 \mathrm{~m}: \mathrm{H}=1.5, \mathrm{df}=8, \mathrm{P}=0.9>0.05 ; 20 \mathrm{~m}: \mathrm{H}=5.4, \mathrm{df}=8, \mathrm{P}=0.7>$ $0.05 ; 30 \mathrm{~m}: \mathrm{H}=5.8, \mathrm{df}=8, \mathrm{P}=0.7>0.05 ; 40 \mathrm{~m}: \mathrm{H}=4.3, \mathrm{df}=8, \mathrm{P}=0.8>0.05 ; 50 \mathrm{~m}: \mathrm{H}=2.4, \mathrm{df}=8, \mathrm{P}=0.9>$ $0.05 ;$ ). The prevailing winds were from the south-east

\subsection{Effect of Distances between Traps}

The largest numbers of $I$. sibirica were captured in the traps placed $30 \mathrm{~m}$ apart $(\mathrm{H}=116.6, \mathrm{df}=4, \mathrm{P}=0<0.05)$ (Figure 3), but no significant difference in captures among traps placed more than $30 \mathrm{~m}$ apart $(\mathrm{H}=1.6, \mathrm{df}=2, \mathrm{P}=$ $0.44>0.05$ ) (Figure 3). The capture density (males captured per square meter) depended on the distance among traps: the greater the distance, the smaller the capture density (Figure 4). At intertrap distance of $30 \mathrm{~m}$ or greater, capture density stabilized and traps did not compete with each other (Figure 4). 


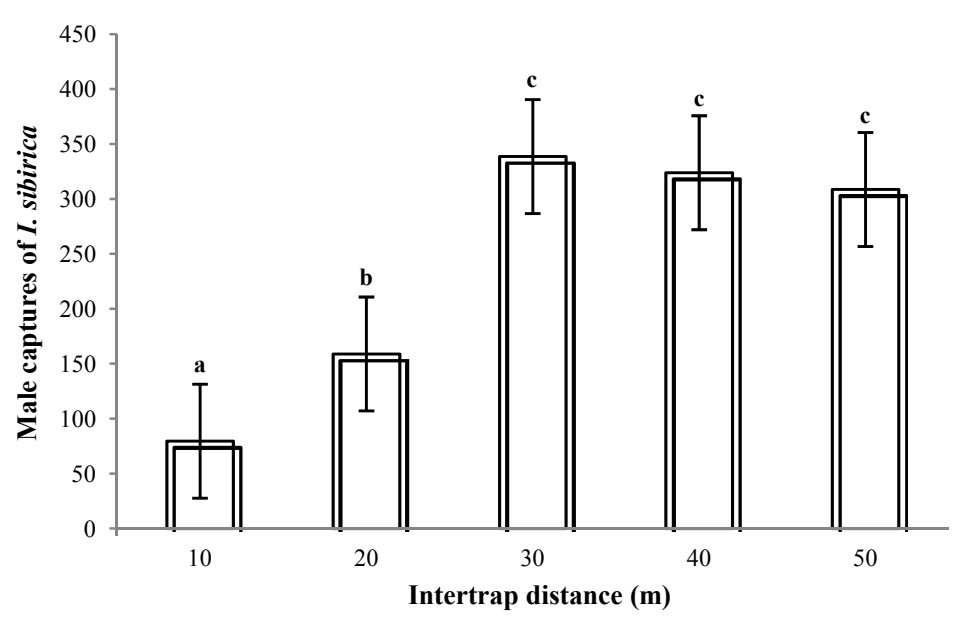

Figure 3. Effect of intertrap distance among traps and mean number $( \pm \mathrm{SE})$ of male $I$. sibirica moths captured in the whole period corresponding to peak moth flight $(\mathrm{H}=116.6, \mathrm{df}=4, \mathrm{P}=0<0.05 ; \mathrm{n}=1800$ traps $)$

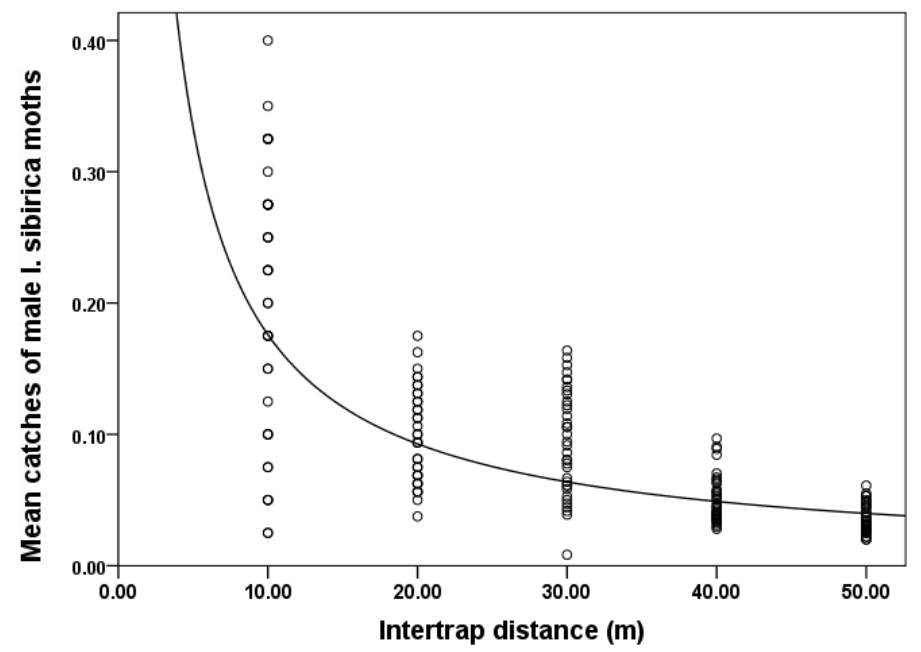

Figure 4. Relationship between capture of male $I$. sibirica moths per square meter and distance among traps $\left(\mathrm{y}=3.931 x^{-0.50}, \mathrm{R}^{2}=0.930, F=54.2\right.$, d.f. $\left.=4,179, P<0.0001 ; \mathrm{n}=1800\right)$

\section{Discussion}

For trap spacing, the present results show that capture density stabilized and traps did not compete with each other at intertrap distance of $30 \mathrm{~m}$ or greater, suggesting $30 \mathrm{~m}$ should be the minimum intertrap distance for monitoring I. sibirica. The interference between traps occurred when intertrap distances were shorter than $30 \mathrm{~m}$, the reason is that the short distances among traps can lead to competition among the pheromone plumes of neighboring traps (Wedding et al., 1995; Wall \& Perry, 1982; Bacca et al., 2006; Elkinton \& Cardé, 1988).

For trap orientation, we found higher catches of male I. sibirica moths in upwind than in other traps regardless of intertrap distances but differences were not significant. Pheromone plumes from traps deployed upwind apparently prevented captures in traps deployed downwind (Wall \& Perry, 1982; Knight et al., 2007).

Our results indicate that trap orientation and intertrap distance significantly affect mean catch of $I$. sibirica in pheromone-baited traps and should thus be considered when using traps to monitor or control I. sibirica in Asparagus growing areas. Trap interval distances should be adjusted depending on the circumstances. An intertrap distance of over $30 \mathrm{~m}$ would be suitable for monitoring and mass trapping of $I$. sibirica, respectively. 


\section{Acknowledgements}

This research was supported by the National $12^{\text {th }}$ Five-year Science and Technology Support Plan of China (Grant no.2012BAD19B07) and the Research Foundation of the Introduction of Talents of Shanxi Agricultural University (Grant no.2014ZZ09).

\section{References}

Bacca, T., Lima, E. R., Picanço, M. C., Guedes, R. N. C., \& Viana, J. H. M. (2006). Optimum spacing of pheromone traps for monitoring the coffee leaf miner Leucoptera coffeella. Entomologia Experimentalis et Applicata, 119, 39-45. http://dx.doi.org/10.1111/j.1570-7458.2006.00389.x

Byers, J. A. (1999). Effects of attraction radius and flight paths on catch of scolytid beetles dispersing outward through rings of pheromone traps. Journal of Chemical Ecology, 25, 985-1005. http://dx.doi.org/10.1023/A:1020869422943

Bradshaw, J. W. S., Ellis, N. W., Hand, S. C., \& Stoakley, J. T. (1989). Interactions between pheromone traps with different strength lures for the pine beauty moth, Panolis flammea (Lepidoptera: Noctuidae). Journal of Chemical Ecology, 15, 2485-2494. http://dx.doi.org/10.1007/BF01020378.

Duan, G. Q., Zhang, Z. B., Zhang, H. J., Du, Y. Q., Hua, B. Z., \& Ma, L. P. (2008). The bionomics of Isoceras sibirica. Chinese Bull Entomol, 45(3), 397-400. http://dx.doi.org/10.3969/j.issn.0452-8255.2008.03.012

Elkinton, J. S., \& Cardé, R. T. (1988). Effects of intertrap distance and wind direction on the interaction of gypsy moth (Lepidoptera: Lymantriidae) pheromone-baited traps. Environmental Entomology, 17, 764-769. http://dx.doi.org/10.1093/ee/17.5.764

Haynes, K. F., Miller, T. A., Staten, R. T., Li, W. G., \& Baker, T. C. (1986). Monitoring insecticide resistance with insect pheromones. Experienlia, 42, 1293-95. http://dx.doi.org/10.1007/BF01946429

Haynes, K. F., Miller, T. A., Staten, R. T., Li, W. G., \& Baker, T. C. (1987). Pheromone trap for monitoring insecticide resistance in the pink bollworm moth (Lepidoptera: Gelechiidae): New tool for resistance management. Environmental Entomology, 16, 84-89. http://dx.doi.org/10.1093/ee/16.1.84

Higbee, B. S., \& Burks, C. S. (2008). Effects of mating disruption treatments on Navel orangeworm (Lepidoptera: Pyralidae) sexual communication and damage in almonds and pistachios. Journal of Chemical Ecology, 101, 1633-1642. http://dx.doi.org/10.1603/0022-0493(2008)101[1633:EOMDTO] 2.0.CO;2

Il'Ichev, A. L., Stelinski, L. L., Williams, D. G., \& Gut, L. J. (2006). Sprayable microencapsulated sex pheromone formulation for mating disruption of Oriental fruit moth (Lepidoptera: Tortricidae) in Australian peach and pear orchards. Journal of Chemical Ecology, 99, 2048-2054.

Judd, G. J. R., \& Borden, J. H. (1989). Distant olfactory response of the onion fly, Delia antiqua to host-plant odour in the field. Physiological Entomology, 14, 429-441. http://dx.doi.org/10.1111/j.1365-3032.1989.tb01112.x

Jansson, R. K., Heath, R. R., \& Coffelt, J. A. (1989). Temporal and spatial patterns of sweet potato weevil (Coleoptera: Curculionidae) counts in pheromone-baited traps in sweet potato fields in southern Florida. Environmental Entomology, 18, 691-697. http://dx.doi.org/10.1093/ee/18.4.691

Kehat, M., Eitam, A., Blumberg, D., Dunkelblum, E., \& Anshelevish, L. (1992). Sex pheromone traps for detecting and monitoring the raisin moth, Cadra figulilella, in date palm plantations. Phytoparasitica, 20(2), 99-106. http://dx.doi.org/10.1007/BF02981275

Knight, A. L. (2007). Influence of within-orchard trap placement on catch of codling moth (Lepidoptera: Tortricidae) in sex pheromone-treated orchards. Environmental Entomology, 36, 425-432. http://dx.doi.org/10.1603/0046-225X(2007)36[425:IOWTPO]2.0.CO;2

Laboke P. O., Ogenga-Latigo, M. W., Smit, N. E. J., Downham, M. C. A., Odongo, B., Hall, D. R., \& Farman, D. (2000). Environmental factors affecting catches of sweat potato weevils, Cylas brunneus (Fabricius) and $C$. puncticollis (Boheman) in pheromone traps. African Potato Association Conference Proceedings, 5, 217-227.

Murad, Z. (2001). Using pheromones to trap banana weevil borers. Banana Topics, DPI South Johnstone, Australia.

Patricia, L. S., Mochel, G., \& Julio, K. (2008). Effect of pheromone trap density on mass trapping of male potato 
tuber moth Phthorimaea operculella (Zeller) (Lepidoptera: Gelechiidae), and level of damage on potato tubers. Chilean Journal of Agricultural Research, 69(2), 281-285.

Stelinski, L. L., McGhee, P., Haas, M., \& Il'ichev, A. L. (2007). Sprayable microencapsulated sex pheromone formulations for mating disruption of four tortricid species: Effects of application height, rate, frequency, and sticker adjuvant. Journal of Economic Entomology, 100, 1360-1369. http://dx.doi.org/10.1603/0022-0493(2007)100[1360:SMSPFF]2.0.CO;2

Schlyter, F. (1992). Sampling range, attraction range and effective attraction radius: estimates of trap efficiency and communication distance in coleopteran pheromone and host attractant systems. Journal of Applied Entomology, 114, 439-454. http://dx.doi.org/10.1111/j.1439-0418.1992.tb01150.x

Sappington, T. W., \& Spurgeon, D. W. (2000). Variation in boll weevil (Coleoptera: Curculionidae) captures in pheromone traps arising from wind speed moderation by brush lines. Environmental Entomology, 29, 807-814. http://dx.doi.org/10.1603/0046-225X-29.4.807

Sarzynski, E. M., \& Liburd, O. E. (2004). Effect of trap height and within - planting location on captures of cranberry fruitworm (Lepidoptera: Pyralidae) in highbush blueberries. Agricultural and Forest Entomology, 6(3), 199-204. http://dx.doi.org/10.1111/j.1461-9555.2004.00222.x

Schlyte, R. F. (1992). Sampling range, attraction range and effective attraction radius: estimates of trap efficiency and communication distance in coleopteran pheromone and host attractant systems. Journal of Applied Entomology, 114, 439-454. http://dx.doi.org/10.1111/j.1439-0418.1992.tb01150.x

Sappington, T. W., \& Spurgeon, D. W. (2000). Variation in boll weevil (Coleoptera: Curculionidae) captures in pheromone traps arising from wind speed moderation by brush lines. Environmental Entomology, 29, 807-814. http://dx.doi.org/10.1603/0046-225X-29.4.807

Wall, C., \& Perry, J. N. (1982). The behaviour of moths responding to pheromone sources in the field: A basis for discussion. Les Colloques de I'INRA, 7, 169-186.

Snedecor, G. W., \& Cochran, W. G. (1967). Statistical methods. Iowa State University Press, Ames, IA.

Wedding, R., Anderbrant, O., \& Jönsson, P. (1995). Influence of wind conditions and intertrap spacing on pheromone trap catches of European pine sawfly, Neodiprion sertifer. Entomologia Experimentalis et Applicata, 77, 223-232. http://dx.doi.org/10.1111/j.1570-7458.1995.tb02005.x

Zhang, G. F., Meng, X. Z., Han, Y., \& Sheng, C. F. (2002). Chinese tortrix Cydia trasias (Lepidoptera: Olethreutidae): Suppression on street-planting trees by mass trapping with sex pheromone traps. Environmental Entomology. http://dx.doi.org/10.1603/0046-225X-31.4.602

Zhang, J. T., \& Liu, H. X. (2011). Identification of the Sex Pheromone of the Asparagus Carpenterworm, Isoceras sibirica Alpheraky (Lepidoptera: Cossidae). Zeischrift Fur Naturforschung Section, 66c, 527-533.

\section{Copyrights}

Copyright for this article is retained by the author(s), with first publication rights granted to the journal.

This is an open-access article distributed under the terms and conditions of the Creative Commons Attribution license (http://creativecommons.org/licenses/by/3.0/). 